\title{
Domateste bakteriyel benek hastalığının biyolojik mücadelesinde farklı bitki aktivatörleri ve biyolojik preparatların etkisi
}

The effect of different plant activators and biological preparete on the biological control of bacterial speck disease in tomato

\section{Benian PInar AKTEPE ${ }^{1 / \mathscr{O}}$ iD}

${ }^{1}$ Osmaniye Korkut Ata Üniversitesi, Kadirli Uygulamalı Bilimler Yüksekokulu, Organik Tarım İşletmeciliği Bölümü, Osmaniye,Türkiye.

MAKALE BILGISI / ARTICLE INFO

\section{Makale tarihçesi / Article history:}

DOI: $10.37908 / m k u t b d .908921$

Geliş tarihi /Received:03.04.2021

Kabul tarihi/Accepted:20.05.2021

\section{Keywords:}

Activator, biological control, Pseudomonas syringae pv. tomato, organic agriculture, sustainable agriculture.

Corresponding author: B.P. Aktepe

$\bowtie$ : benianaktepe@gmail.com

\author{
ÖZET / A B STRACT
}

Atıf / Citation: Aktepe BP (2021) The effect of different plant activators and biological preparete on the biological control of bacterial speck disease in tomato. MKU. Tar. Bil. Derg. 26(2) : 355-364. DOI: 10.37908/mkutbd.908921

\section{GíRiş}

Dünya nüfusunun sürekli artması ile gıda ihtiyacı da artmaktadır. Birim alandan yüksek verim elde etmek için tarım alanlarında bilinçsizce kimyasal gübre, hormon ve pestisit kullanılmaktadır. Sonuçta, bu durum doğal ekosistemin bozulmasına, su ve hava kirliliğinin artmasına, toprak verimliliğinin azalmasına ve insan sağı̆̆̆ının bozulmasına yol açmaktadır (Kiracı ve Karataş, 2015). Bu olumsuz etkileri azaltmak için konvansiyonel tarımsal uygulamaların dışında sürdürülebilir üretim yöntemi olan "Organik, Biyolojik, Ekolojik Tarım" çevre dostu üretim şekli olarak ön plana çıkmaktadır. Organik üretim, toprak organizmaları, bitkiler, hayvanlar ve 
insanlar dahil olmak üzere, tarımsal ekosistemin üretkenliğini ve uygunluğunu optimize etmek için tasarlanmış bütünsel bir sistemdir. Bu üretim şeklinin temel amacı, sürdürülebilir ve çevre ile uyumlu işletmeler geliştirmektir. Son 14 yılın Tüik (Türkiye İstatistik Kurumu) verileri incelendiğinde organik bitkisel üretimin beş kat artmıştır. Bu nedenle hastalık-zararlı yönetiminde çevre dostu, insan sağlığı açısından güvenli, ekonomik ve etkili yöntemleri kullanmak önemli hale gelmiştir (Anonim, 2021a).

Bitkisel üretimin en önemli mahsüllerinden biri, insanlık için stratejik ve oldukça karlı bir mahsul olan domatestir. Domates (Lycopersicon esculentum), patlıcangiller familyasında yer alan, anavatanı Güney ve Orta Amerika olan taze veya işlem görmüş şekilde tüketilebilen bir sebze türüdür. llık ve sıcak iklim meyvesi olan domates, 19. Yüzyılda Fransa ve Suriye üzerinden ülkemize ülkemize gelerek üretim ve tüketimi artarak devam eden, yüksek besin içeriğinin olmasının yanında tarımsal saniye de entegre olan önemli bir ticari üründür (Karaer, 2020). Domates, yüksek oranda potasyum, organik asitler, likopen ve $\beta$-karoten gibi karotenoidler bakımından da oldukça zengin, $A$ ve $C$ vitaminleri bakımından önemli bir kaynak niteliği taşımaktadır (Sönmez, 2016). Dünyada 1.1 milyar tonluk sebze üretiminin yaklaşık 180 milyon tonunu domates üretimi oluşturmaktadır. Türkiye, FAO (Food and Agriculture Organization; Gıda ve Tarım Örgütü) 2019 verilerine göre 12.841.990 ton üretimle dünyada üçüncü sırada yer almaktadır (Anonim, 2021b). TÜik 2020 verilerine göre ülkemizde domates üretimi yoğun olarak Akdeniz ve Ege Bölgesinde yapılmakta olup bunu Marmra Bölgesi takip etmektedir (Anonim, 2021c)

Domates üretiminde verim ve kaliteyi etkileyen pek çok hastalık ve zararlı bulunmaktadır. Agrobacterium, Clavibacter, Pectobacterium, Pseudomonas, Ralstonia, Xanthomonas cinslerine ait $10^{\prime}$ dan fazla tür domateste bakteriyel hastalıklara neden olmaktadır. Pseudomonas syringae pv. tomato'nun neden olduğu bakteriyel kara leke veya bakteriyel benek hastalığı da fidelik, örtü altı ve açıkta yetiştirilen domateslerde önemli kayıplara neden olan bir bakteriyel hastalıktır. Hastalık etmeni, çiçek, meyve, yaprak ve gövde gibi domates bitkisinin tüm toprak üstü organlarını hastalandırmaktadır. Tohumla taşınan bu hastalık etmeni, tohum kabuğundan kotiledon yapraklarda nekrozlar belirtilerine neden olur (Jones ve ark., 2014). Daha sonra Bu lekeler birleşerek yaprağın kısmen veya tamamen kurumasına neden olur. Hastalığın en tipik meyve belirtisi $1 \mathrm{~mm}$ çapında dışa çıkık lekelerdir. iklim koşulları uygun olduğunda hastalıklı bitki oranı özellikle örtü altında \%75 civarında olabilmektedir. Şiddetli enfeksiyonlarda domates serasında \%12-23'e kadar varan ürün kaybı olabilmektedir (Aysan ve Saygılı, 2008).

Tohum kökenli bu hastalık etmenine karşı tek bir yöntem yerine birkaç mücadele yönteminin birlikte kullanıldı̆̆ı entegre mücadele önem kazanmış durumdadır. Geleneksel ve organik üretim yapan çiftçiler, hastalıkzararlı yönetiminde sürdürülebilir çözümler sağlayan ve kimyasal pestisitlere alternatif olabilecek kültürel ve yenilikçi mücadele stratejilerine ihtiyaç duymaktadır. Bu uygulamalardan kültürel mücadele kapsamında, dayanıklı bitki kullanımı, tuzaklardan yararlanma topraktaki organik madde miktarını ve toprağın içerdiği mikrobiyal popülasyonun artışını sağlayan ürün rotasyonu, örtücü bitkiler, kompost ve işlenmiş hayvan ve solucan gübrelerinin kullanımıdır (Soylu ve ark., 2020). Hastalıklarla kimyasal mücadeleye alternatif olarak bitki uçucu yağ ve ekstraktların kullanımı, nanoteknolojik ürünlerin kullanıldığı yaklaşımlar, fungal, bakteriyel ve viral kökenli biyolojik etmenlerden geliştirilmiş biyopreparatlar, bitkileri hastalıklara dayanıklı uyaran biyotik ve abiyotik "Bitki Aktivatörleri"'nin kullanımı sayılabilir (Mengulluoglu ve Soylu, 2012; Kiracı ve Karataş, 2015; Sülü ve ark., 2016; Bozkurt ve ark., 2020; Şahin ve ark., 2021). Bitki aktivatörleri uygulandığında, bitki hücresinde tanıyıcı (reseptörler) patojen mikroorganizma varlığını algılamışçasına hücrelere sinyal göndererek mikroorganizma saldırılarına karşı koymak için bitki hücrelerinde morfolojik ve biyokimyasal savunma sistemini aktif hale getirir (Soylu ve ark., 2003). Bitkide mevcut olan doğal savunma sisteminin harekete geçirilmesiyle gerçekleşen dayanıklılığın devreye girmesiyle bitki patojenlere karşı uzun süreli korurken, bitkide yüksek verimlilik sağlanmaktadır. Bitkinin muhtemel bir saldırıya karşı en üst düzeyde alarmda kalmasını ve kendini en iyi şekilde savunabilmesini sağlamak, patojen organizmaların bitki dokusuna tutunmasını zorlaştırır. Böylece, hastalık düzeyi azalmış olur (Akbaş, 2018). Bu uygulamalar bitkiyi birkaç haftadan birkaç aya kadar değişebilen bir süre içinde, pek çok hastalık etmenine karşı koruyabilmektedir (Aktaş ve Güven, 2005; Delisoy ve Altınok, 2019). Bitkide dayanıklılık mekanizmasını tetikleyen ve enfeksiyonlara karşı bitkiyi koruyan bitki aktivatörü uygulamaları bunlara ek olarak, bitkilerin çiçeklenme ve meyve tutum miktarını artırarak yüksek verimlilik sağlar. Biyotik uyaranlara sistemik bir yanıt, sistemik edinilmiş direnç (SAR) olarak adlandırılırken abiyotik uyaranlara sistemik edinilmiş alışma (SAA) olarak adlandırılır. Çevresel uyaranlara sistemik tepkiler, çok hücreli organizmaların hayatta kalması için gereklidir. Tüm bu sistemik tepkilerin sonucunda bitkinin tüm dokularını biyotik veya 
abiyotik bir tehdidin varlığına karşı uyarılırak bu dokulardaki direnç veya alışma yollarının aktivasyonunu tetiklemektir. Son yıllarda, bitkilerde sistemik sinyale aracılık etmede bir takım kimyasallar ve bileşikler yer almıştır. Bunlar arasında salisilik asit ve metil salisilat, jasmonik asit ve metil jasmonat, azelaik asit, oksin, etilen, absisik asit (ABA), pestisitler (Butsenko ve ark,2020), reaktif oksijen türleri (ROS) (Hernandeza ve ark, 2019), farklı peptidler ve proteinler, elektrik sinyalleri ve RNA molekülleri bulunmaktadır. Henüz strese veya patojene maruz kalmamış dokularda direnç veya alışma yollarının etkinleştirilmesi, bitkinin yaklaşan biyotik veya abiyotik tehditlere dayanmasını ve hayatta kalmasını sağlayacaktır (Mittler ve Blumwald, 2015).

$\mathrm{Bu}$ çalışmada hastalıklarla kimyasal mücadeleye alternatif olarak organik tarımda kullanılabilen bazı bitki aktivatörleri ve bir biyolojik preparatın domateste Pseudomonas syringae pv. tomato tarafından neden olunan bakteriyel benek hastalığını baskılama potansiyelleri araştırılmıştır. Ülkemizde yapılan çalışmalarda, bitki aktivatörlerinden Turf-Set, KingBo ve Sergomil'in Pseudomonas syringae pv. tomato'ya karşı etkisiyle ilgili çalışmalara rastlanılmamıştır. Bu aktivatörlerin domateste bakteriyel benek hastalığına etkisi ilk defa bu çalışma ile ortaya konmuştur. Ayrıca uygulamaların hastalık gelişimini baskılamalarının yanısıra bitki büyümesine olan etkilerini ortaya koymak için bitki biyomas (kuru ağırlık) verileri değerlendirilmiştir.

Çizelge 1. Çalışmada kullanılan preparatlar ve özellikleri

Table 1. The preparations used in the study and their properties

\begin{tabular}{ccccc} 
Preparat & Aktif madde & Firma & Etki şekli & $\begin{array}{c}\text { Doz } \\
(\mathbf{1 0 0 l t})\end{array}$ \\
\hline Crop-Set & $\begin{array}{l}893,80 \mathrm{~g} / \text { I Lactobacillus acidophilus fermentasyon ürünü, } \\
\text { Yucca bitki ekstraktı, \%1.2 Sülfür, \%0.2 Bakır, \%0.6 Demir, } \\
\text { \%1.5 Manganez }\end{array}$ & Improcrop & Bitki aktivatörü & $60 \mathrm{ml}$ \\
\hline
\end{tabular}

$855,81 \mathrm{~g} / \mathrm{l}$ Lactobacillus acidophilus fermentasyon ürünü,

ISR-2000 Yucca bitki ekstraktı, maya ekstraktı, riboflavin, benzoik asit, Improcrop Bitki aktivatörü $100 \mathrm{ml}$ nikotinamid ve thiamine

\begin{tabular}{lcccc}
\hline KingBo & Bitkisel kaynaklı hammaddelerden üretilmiştir & $\begin{array}{c}\text { KingBo } \\
\text { Biotech }\end{array}$ & Bitki aktivatörü & $150 \mathrm{ml}$ \\
\hline Sergomil L60 & $\begin{array}{c}\text { \%5,5 bitkisel kaynaklı bakır, bitkisel kaynaklı fenoller ve } \\
\text { fitoaleksinler içerir. }\end{array}$ & Agrobank & Bitki aktivatörü & $100 \mathrm{ml}$ \\
\hline $\begin{array}{l}\text { Turf-Set } \\
\text { Serenade }\end{array}$ & $\begin{array}{c}\text { İ elementleri, vitaminler, aminoasitler, bitki ekstraktı, ve } \\
\text { Lactobacillus fermantasyon ürünü }\end{array}$ & Improcrop & Bitki aktivatörü & $100 \mathrm{ml}$ \\
\hline & Bacillus subtilis QST 713 & Bayer & $\begin{array}{c}\text { Biyolojik } \\
\text { preparat }\end{array}$ & $100 \mathrm{ml}$ \\
\hline
\end{tabular}

\section{Bitki materyali ve uygulamalar}

Çalışmada kullanılan Retinto F1 çeşidi domates fideleri, ticari bir fide üretim şirketi olan Hishtil Fide A.S.'den (ADANA/Sarıçam) temin edilmiştir. Tüm in vivo etkinlik çalışmaları Osmaniye Korkut Ata Üniversitesi Organik Tarım İşletmeciliği bölüm arazisinde bulunan deneme boyunca gündüz $20-28^{\circ} \mathrm{C}$ ve gece $10-16^{\circ} \mathrm{C}$ sıcaklığa ve yaklaşık \%40-60 bağıl neme sahip $12 \mathrm{~m}^{2}$ büyüklüğündeki plastik seralarında yürütülmüştür.

Çalışmada Çukurova Üniversitesi Ziraat Fakültesi Bitki Koruma Bölümü öğretim üyesi Prof. Dr. Yeşim AYSAN'ın kültür koleksiyonunda bulunan ve farklı bölgelerden izole edilerek daha önceden farklı yöntemlerle kesin tanısı yapılmış YA-11, YA-12, YA-13, YA-14 ve YA-15 kodlu Pseudomonas syringae pv. tomato izolatları kullanılmıştır. $\mathrm{Bu}$ araştırıcıdan temin edilen patojen bakteri izolatları King $\mathrm{B}$ besiyerinde 48 saat geliştirilmiş ve beş farklı izolattan hazırlanan $10^{7}$ hücre $/ \mathrm{ml}$ yoğunluğunda süspansiyonların eşit karışımları çalışmada kullanılmıştır.

Hastalıkla mücadelede Bitki aktivatörü olarak Crop-Set, ISR-2000, KingBo, Sergomil, Turf-Set kullanılmıştır. Serenade ise biyolojik preparat olarak çalışmaya dahil edilmiştir. Çalışmada kullanılan preparatların özellikleri ve içerikleri Çizelge 1 'de verilmiştir. 


\section{Bitki aktivatörleri ve biyolojik preparatın bakteriyel benek hastalığına etkisi}

Tablo 1'de görüldüğü gibi, bitki aktivatörleri (Crop-Set, ISR-2000, KingBo, Sergomil, Turf-Set) ve biyolojik preparat (Serenade) üretici firmanın tavsiyesine göre, önerilen dozda hazırlanmıştır. Retinto F1 çeşidi domates fidelerinin toprağa şaşırtılmasından dört gün sonra el pülverizatörleri ile tüm yeşil aksama püskürtülmüştür. Püskürtmeler, bir hafta arayla toplamda üç kez yinelenmiştir. Ardından patojen bakterinin beş farklı izolatının eşit karışımından oluşan $10^{7}$ hücre $/ \mathrm{ml}$ yoğunluğunda süspansiyonu tüm yeşil aksama bir el pülverizatörüyle püskürtülmüştür. Pozitif kontrol bitkilerine herhangi bir uygulama yapılmamış sadece patojen bakteri süspansiyonu püskürtülürken negatif kontrol bitkilerine sadece steril su püskürtülmüştür. Çalışmada sekiz farklı uygulama ve her uygulamada beş domates bitkisi olmak üzere toplam 40 domates bitkisiyle sera denemesi kurulmuştur.

Deneme boyunca bitkiler hastalık gelişimi açısından günlük olarak incelenmiştir. Pozitif kontrolde gözle görülür hastalık belirtileri oluştuktan sonra bitkinin orta kısmındaki hastalıklı beş yaprak incelenmiş ve benek belirtileri Karman (1971)'e göre modifiye edilerek oluşturulan 0-5 skalasına (0: hastalık belirtisi yok; 1 : yaprağın \%1-10'unda hastalık belirtisi var; 2: yaprağın \% 11-25'inde hastalık belirtisi var; 3: yaprağın \% 26-50'inde hastalık belirtisi var; 4: yaprağın \% 51-75'ında hastalık belirtisi var; 5: yaprağın \% 76'sından fazla hastalık belirtisi var) göre değerlendirilmiştir. İlk değerlendirme yapıldıktan sonra yapraklardaki hastalık birer hafta arayla toplamda üç kez değerlendirilerek hastalığın ilerleme düzeyi kaydedilmiştir.

Gövdelerdeki lezyon belirtileri patojen inokulasyonundan 20 gün sonra Karman (1971)'e göre modifiye edilerek oluşturulan 0-5 skalasına (0: leke yok; 1: 3 mm'den küçük 1-6 adet leke; 2: 3mm'den küçük 715 leke; 3: 3mm'den büyük 1-6 leke; 4: 3mm'den büyük 7-15 leke; 5: 3mm'den büyük 15 lekeden çok) göre yapılmıştır. Illk değerlendirme yapıldıktan 21 gün sonra gövdedeki hastalık belirtileri ikinci kez değerlendirilerek kaydedilmiştir.

Elde edilen skala değerleri Towsend-Heuberger formülünden faydalanılarak hastalık şiddetine dönüştürülmüştür. Uygulamaların hastalığa etkisi pozitif kontrolle karşılaştırılarak Abbot formülüne göre hesaplanmıştır (Karman, 1971). Uygulamalar arasındaki istatistiki farklar hesaplanırken, LSD çoklu karşılaştırma testinde $p \leq 0.05$ önem düzeyinde analizler yapılmıştır. Aynı istatistiki grupta yer alan uygulamalar aynı harfle işaretlenerek gruplandırımış ve sonuçlar yorumlanmıştır.
Bitki aktivatörleri ve biyolojik preparatın bitki büyümesine etkisi

Bitkiler hasada kadar yetiştirilerek meyve verimi alınamadığından uygulamaların bitki büyümesine etkisini ortaya koymak için bitki biyomas (kuru ağırlık) verileri alınmıştır. Hastalık açısından değerlendirme yapıldıktan sonra bitkiler, kök boğazından kesilerek kese kağıtlarına konulmuş, ağızları kapatılmış, üzeri etiketlenerek $65^{\circ} \mathrm{C}$ etüvde 10 gün bırakılarak kurumaları sağlanmıştır (Inbar, 1994). Kurutulmuş bitkiler hassas terazide tartılarak kuru ağırlıkları kaydedilmiştir. Sadece patojen bulaştırılmış pozitif kontroldeki kuru ağırlıkla uygulama görmüş bitkilerdeki kuru ağırlığı karşılaştırılarak etki oranı (\%) Abbot formülüyle hesaplanmıştır. Uygulamalar arasındaki istatistiki farklar Anova istatistik programında LSD çoklu karşılaştırma testinde $p \leq 0.05$ önem düzeyine göre aynı istatistiki grupta yer alan uygulamalar aynı harfle işaretlenerek sonuçlar yorumlanmıştır.

\section{BULGULAR ve TARTIŞMA}

\section{Bitki aktivatörleri ve biyolojik preparatın domateste bakteriyel benek hastalığına karşı etkisi}

Domates bitkilerine beş farklı bitki aktivatörü ve biyolojik preparat yeşil aksama püskürtme şeklinde uygulandıktan sonra bitkilere patojen bakteri inokule edilmiş ve ilk hastalık belirtileri patojenin inokulasyonundan 20 gün sonra gözlenmiştir. Çizelge 2 ve Şekil 1'de görüldüğü gibi, yapılan ilk değerlendirmede pozitif kontrol bitkilerinde ortalama hastalık oranı \%63.33 olarak belirlenirken "Sergomil" uygulanan bitkilerde hastalık oranı ortalama \%33.33 olarak tespit edilmiş ve yapraklardaki benek şeklinde görülen hastalık belirtilerinin \%47.37 oranında baskılandığı saptanmıştır. İstatistiksel olarak incelendiğinde, "Sergomil" uygulaması ayrı bir grupta yer alan en başarılı uygulama olmuştur. Diğer bir başarılı uygulama grubu içerisinde "Turf-Set" ve "ISR-2000" yer almış ve bu iki uygulama da yapraklardaki benek belirtilerini \%31.58 oranında azaltmıştır. "Crop-Set" ve "KingBo" uygulamaları ise istatistiksel olarak diğer bir başarılı grubu oluşturmuştur. "Crop-Set" uygulaması \%26.31, "KingBo" uygulaması ise \%21.05 oranında yapraklardaki hastalığı azaltmıştır. Biyolojik preparat olan "Seranade" uygulaması hastalığı sadece \%15.79 oranında baskılamış ve istatistiksel olarak değerlendirildiğinde etkisiz bir uygulama olarak belirlenmiştir.

Bir hafta sonra yapılan ikinci yeşil aksam incelemelerinde ne pozitif kontrolde ne de uygulama yapılan bitkilerde hastalık düzeyinde bir değişiklik olmamıştır (Çizelge 2 ve Şekil 1). Illk değerlendirmeden 14 gün sonra yapılan 
üçüncü değerlendirmede pozitif kontrol bitkilerinde hastalığın ilerlemeye devam ettiği ve oranın \%63.33'ten \%66.67'ye yükseldiği tespit edilmiştir. Pozitif kontrol bitkilerin yeşil aksamında hastalık ilerlemesi devam ederken Sergomil, Turf-Set, ISR-2000, KingBo ve Serenade uygulamalarında benek belirtileri düzeyinde üç hafta boyunca artış görülmemiştir. Delisoy ve Altınok (2019) tarafından yapılan bir çalışmada bu çalışmada elde edilen bulguları destekler şekilde sonuçlar alınmış ve aktivatörlerin bitkide sistemik dayanıklılı̆ı uyararak patojenlere karşı uzun süreli korumanın sağlandığı belirtilmiştir. Araştırmalarında yer alan bitki aktivatorlerinden, kavunda Fusarium solgunluk hastalığına karşı pozitif kontrole gore $\% 49.25$ etki göstererek SAR mekanizmasını en iyi teşvik eden aktivatorun AuxiGro olduğu belirtmişlerdir. Crop- Set ve ISR-2000 aktivatörlerinin ise \%41.79 ve 35.82 oranında hastalığı baskıladığını rapor etmişlerdir. Ayrıca SAR mekanizmasının aktif olduktan sonra etkinliğininbitki bunyesinde birkac hafta sürdüğünü ve böylece bitkinin dışarıdan gelecek sadırılara karşıkorunduğunu vurgulamışlardır. Gonzalez-Hernandeza ve ark (2019), karbon ve nitrojen metabolizmalarında amonyum aracılı değişikliklerin domates bitkilerinde Pseudomonas syringae pv. tomato'ya karşı direnci nasıl teşvik ettiğini araştırdıkları çalışmada baskın $\mathrm{NH}^{+}$uygulamasının metabolik değişiklikleri teşvik eden bir "amonyum sendromuna" neden olduğunu ve böylece sistemik edinilmiş alışma (SAA) aktivasyonu yoluyla Pseudomonas syringae pv. tomato enfeksiyonuna karşı direnç sağladığını saptamışlardır. $\mathrm{NH}^{+}$ile beslenen bitkiler, SAA'yı aktive ederek besin dengesizlikleri ve birincil metabolizmadaki değişiklikler yoluyla Pseudomonas syringae pv. tomato'ya karşı direnci tetiklemeye olanak tanıyan yüksek düzeyde bazal yanıtlar sergilediğini belirtmişlerdir. Benzer şekilde Butsenko ve ark (2020), domates tarlalarında kullanılan pestisitlerin (aluminium phosethyl-40 mg/L ve deltamethrin $-0.25 \mathrm{mg} / \mathrm{L}$ ), domates bakteri benek hastalığna neden olan Pseudomonas syringae pv. tomato'ya üzerindeki etkisini araştırmışlardır. Fungisit fosetyl-alüminyumun Pseudomonas syringae pv. tomato üzerinde bakteriyostatik bir etkisi olduğunu tespit etmişlerdir. fosetyl-alüminyum fungisitin, streptomisin içeren besiyerinde Pseudomonas syringae pv. tomato'nun $\operatorname{Str}^{R}$ kolonilerinin (antibiyotiğe dirençli) sayısında bir artışa neden olmadığını ancak insektisit deltametrinin uygulandığında $\operatorname{Str}^{R}$ kolonilerinin sayısında artış gözlemlendiğini saptamışlardır. antibiyotik direncinin pestisitlerin mutajenik etkisinin bir sonucu olabileceğini belirterek pestisitlerin fitopatojenik bakteri kolonilerinin büyümesi ve morfolojisi üzerinde etkili olduklarını vurgulamışlardır.

Son hastalık verilerine göre yapılan istatiksel değerlendirme sonucunda, tüm uygulamaların pozitif kontrolden farklı grupta yer alan başarılı uygulamalar olduğu belirlenmiştir. Farklı bitki aktivatörleri ve biyolojik fungisit uygulanmış domates yapraklarında Pseudomonas syringae pv. tomato'nun neden olduğu bakteriyel benek belirtilerinin \%20-50 oranında azaldığı ortaya konmuştur. Negatif kontrol olarak sadece su püskürtülen bitkilerde ise herhangi bir hastalık belirtisi gözlenmemiştir.

Gövde lezyonları açısından yapılan ilk değerlendirmede, tüm uygulamalar hastalığı \%35 ila \%55 oranında baskılayarak başarılı olduğu belirlenmiştir. İstatistiki açıdan değerlendirildiğinde tüm uygulamalar pozitif kontrolden farklı olarak tek bir grupta yer alan başarılı uygulamalar olmuştur (Çizelge 3 ve Şekil 2). illk değerlendirmeden 21 gün sonra yapılan ikinci değerlendirmede gövde lezyonlarının hem pozitif kontrolde hem de uygulama yapılmış bitkilerde ilerlemeye devam ettiği gözlenmiştir. Ancak her ne kadar hastalık ilerlese de yapılan uygulamalar 21 gün sonra bile hastalığı \%25-37.50 oranında baskılamaya devam etmiş ve istatistiki açıdan yine başarılı bulunmuştur.

Çizelge 2. Bitki aktivatörleri ve biyolojik preparatın yapraklarda bakteriyel benek hastalığına etkisi

Table 2. The effect of plant activators and a biopreparat on Bacterial Speck Disease on foliar

\begin{tabular}{lccccc}
\hline & \multicolumn{2}{c}{ 1.değerlendirme } & \multicolumn{2}{c}{ 2.değerlendirme } & 3.değerlendirme \\
\cline { 2 - 6 } Uygulamalar & Hastalık Oranı (\%) & \% Etki & Hastalık Oranı (\%) & \% Etki & Hastalık Oranı (\%) \\
\hline Pozitif Kontrol & $63.33 \mathrm{a} *$ & - & $63.33 \mathrm{a}$ & & $66.67 \mathrm{a}$ \\
Serenade & $53.33 \mathrm{ab}$ & 15.79 & $53.33 \mathrm{ab}$ & 15.79 & $53.33 \mathrm{~b}$ \\
KingBo & $50.00 \mathrm{~b}$ & 21.05 & $50.00 \mathrm{~b}$ & 21.05 & $50.00 \mathrm{~b}$ \\
Crop-Set & $46.67 \mathrm{~b}$ & 26.31 & $46.67 \mathrm{~b}$ & 26.31 & $50.00 \mathrm{~b}$ \\
ISR-2000 & $43.33 \mathrm{bc}$ & 31.58 & $43.33 \mathrm{bc}$ & 31.58 & $43.33 \mathrm{bc}$ \\
Turf-Set & $43.33 \mathrm{bc}$ & 31.58 & $43.33 \mathrm{bc}$ & 31.58 & $43.33 \mathrm{bc}$ \\
Sergomil & $33.33 \mathrm{c}$ & 47.37 & $33.33 \mathrm{c}$ & 47.37 & 35.00 \\
\hline
\end{tabular}

*: Aynı sütunda yer alan ortalama hastalık oranlarının yanındaki aynı harflerle uygulamalar arasında farkın istatistiksel olarak LSD Çoklu Testine göre önemli olmadığını gösterir $(P \leq 0.05)$ 
Çizelge 3. Bitki aktivatörleri ve biyolojik preparatın gövdede bakteriyel benek hastalığına etkisi Table 3. The effect of plant activators and a biopreparat on Bacterial Speck Disease on stem

\begin{tabular}{lcccc}
\hline & \multicolumn{2}{c}{ 1. değerlendirme } & 2. değerlendirme \\
\cline { 2 - 5 } Uygulamalar & Hastalık Oranı (\%) & \% Etki & Hastalık Oranı (\%) & \% Etki \\
\hline Pozitif Kontrol & $80.00 \mathrm{a}^{*}$ & & $96.00 \mathrm{a}$ & \\
Serenade & $52.00 \mathrm{~b}$ & 35.00 & $72.00 \mathrm{~b}$ & 25.00 \\
Sergomil & $52.00 \mathrm{~b}$ & 35.00 & $64.00 \mathrm{~b}$ & 33.33 \\
KingBo & $52.00 \mathrm{~b}$ & 35.00 & $56.00 \mathrm{~b}$ & 41.67 \\
Crop-Set & $40.00 \mathrm{~b}$ & 50.00 & $64.00 \mathrm{~b}$ & 33.33 \\
ISR-2000 & $40.00 \mathrm{~b}$ & 50.00 & $60.00 \mathrm{~b}$ & 37.50 \\
Turf-Set & $36.00 \mathrm{~b}$ & 55.00 & $60.00 \mathrm{~b}$ & 37.50 \\
\hline
\end{tabular}

*: Aynı sütunda yer alan ortalama hastalık oranlarının yanındaki aynı harflerle uygulamalar arasında farkın istatistiksel olarak LSD Çoklu Testine göre önemli olmadığını gösterir $(P \leq 0.05)$

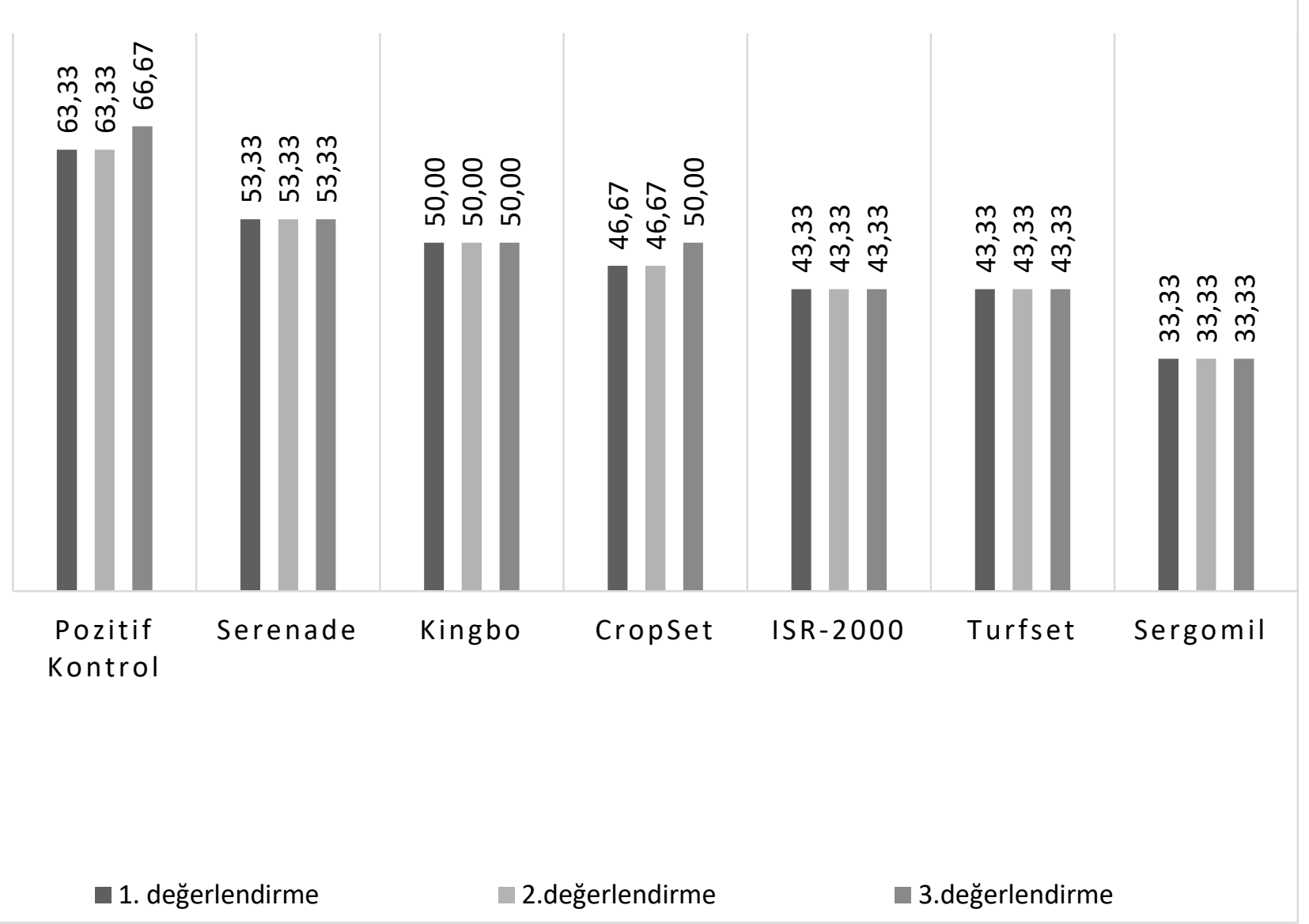

Şekil 1. Patojen inokulasyonundan 7, 14 ve 21 gün sonra domates yapraklarında belirlenen hastalık oranları (\%) Figure 1. Disease rates (\%) determined on tomato leaves 7, 14 and 21 days after pathogen inoculation 


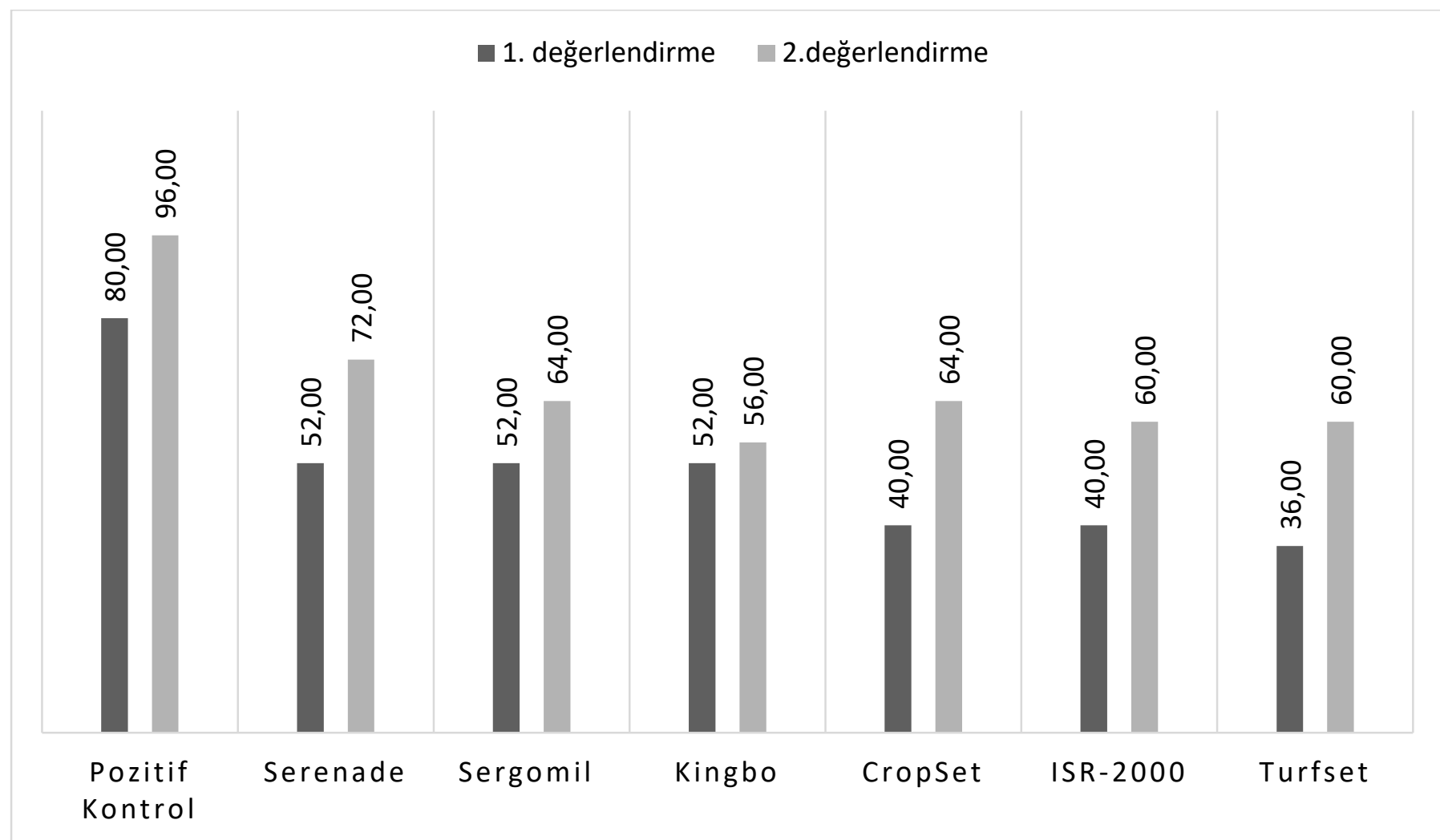

Şekil 2. Patojen inokulasyonundan 7 ve 21 gün sonra domates gövdesinde belirlenen hastalık oranları (\%)

Figure 2. Disease rates (\%) determined on tomato stem 7 and 21 days after pathogen inoculation

Yapılan değerlendirmeler sonucunda, Pseudomonas syringae pv. tomato'nun neden olduğu yapraklardaki benek ve gövdedeki kara leke belirtilerini baskılamada tüm uygulamalar başarılı bulunsa da içlerinden Turf-Set, ISR-2000 ve Sergomil uygulamalarının daha başarılı olduğu sonucuna varılmıştır.

Bu çalışmada elde edilen bulguları destekleyen Herman ve ark. (2008) tarafından yapılan bu hastalığın mücadelesinde bitki aktivatörü Actigard 50 WG kullanılarak hastalık \%38-67 oranında baskılanmıştır. Hastalık azalışında bitki aktivatörünün bitkideki dayanıklıık genlerini aktive ettiği bildirilmiştir. Karabay ve ark. (2003) da bu hastalığın baskılanmasında bitki aktivatörleri (Bion ve Crop-Set) ve bakıroksiklorür (ticari adı Cupracol) kombinasyonun başarıyı artıracağını ve etki süresini uzatacağını belirtmiştir. Bu uygulamalar bitkideki peroksidaz aktivitesini artırarak bitkiyi hastalıktan koruduğunu bildirmişlerdir.

Benzer şekilde domateste farklı bakteri hastalıklarııın mücadelesinde bitki aktivatörlerinin kullanımı son zamanlarda oldukça yaygınlaşmıştır (Herman ve ark., 2008). Domates öz nekrozu hastalığının (Ustun ve ark., 2005) ve bakteriyel solgunluk hastalığının (Baysal ve ark., 2003; Soylu ve ark., 2003; Çetinkaya Yıldız ve Aysan, 2005; Ustun ve ark., 2009; Soykan ve Aysan, 2011) mücadelesinde bitki aktivatörlerinden Bion (acibenzolar-
S-methyl), Messenger (harpin), ISR-2000 ve Crop-Set uygulamalarının etkili olduğunu gösteren pek çok çalışma mevcuttur.

\section{Bitki aktivatörleri ve biyolojik preparatın bitki biyomasına etkisi}

Bitkilerde artan büyüme tepkisi genellikle kuru ağırlıkları ölçülerek belirlenmektedir (Inbar, 1994). Çizelge 4'te görüldüğü gibi uygulama yapılan bitkiler hastalık açısından değerlendirildikten sonra kurutularak kuru ağırlıkları karşılaştırılmış ve en fazla kuru ağırlık artışının sırasıyla Turf-Set, CropSet ve ISR-2000 uygulamalarında olduğu belirlenmiştir. Bu uygulamalar bitki kuru ağırlığını $\% 56 \% 49.92$ ve $\% 47.13$ oranında arttırmış ve istatistiksel olarak başarılı uygulamalar olarak değerlendirilmiştir. Serenade uygulaması bitki kuru ağırlığını \%33.98 oranında artırsa da kontrolle aynı istatistiki grupta yer aldığından başarılı bulunmamıştır. Sergomil ve KingBo uygulamaları ise bitki kuru ağırlığında sadece \%\%3.59 ve \% 8.74 oranında artışa neden olarak bitki büyümesine herhangi bir olumlu etkisinin olmadığı saptanmıştır.

Domates yapraklarındaki bakteriyel benek ve gövdesindeki kara leke hastalık belirtilerinin baskılanmasında öne çıkan Turf-Set ve ISR-2000 uygulamaları bitki büyümesinde de oldukça başarılı bulunmuştur. Daha önce domateste yapılan farklı 
çalışmalarda da bitki aktivatörlerinin domates bitkilerinin kuru ağırlığında artışa neden olduğu bildirilmiştir (Soykan, 2010; Delisoy ve Altıok, 2019; Kiracı ve ark., 2013).

Çizelge 4. Bitki aktivatörleri ve biyolojik preparatın bitki kuru ağırlığına etkisi.

Table 4. The effect of plant activators and biopreparat on dry weight of the plant.

\begin{tabular}{lcc}
\hline Uygulamalar & Ort. Kuru ağırlık (gr) & \% Artış \\
\hline Pozitif Kontrol & $14.16 \mathrm{c}^{*}$ & - \\
KingBo & $14.67 \mathrm{c}$ & 3.59 \\
Sergomil & $15.40 \mathrm{bc}$ & 8.74 \\
Serenade & $18.97 \mathrm{abc}$ & 33.98 \\
ISR-2000 & $20.83 \mathrm{ab}$ & 47.13 \\
Crop-Set & $21.23 \mathrm{a}$ & 49.92 \\
Turf-Set & $22.09 \mathrm{a}$ & 56.00
\end{tabular}

*: Aynı sütunda yer alan ortalama değerlerin yanındaki aynı harflerle uygulamalar arasında farkın istatistiksel olarak LSD Çoklu Testine göre önemli olmadığını gösterir ( $P \leq 0.05)$.

Sonuç olarak, tarımsal üretimde bakteriyel hastalıkların mücadelesinde karantina önlemleri, dayanıklı çeşit kullanımı, kültürel önlemler, tohum uygulamaları ve kimyasal mücadele gibi farklı yöntemler tercih edilir. Bakteriyel hastalıkların gelişimi için uygun iklim şartları oluşmamış ve kullanılan bitki çeşidi yaprak leke hastalıklarına çok duyarı bir çeşit değilse hastalık farklı yöntemlerin kullanımıyla baskılanabilir. Ancak örtü altı yetiştiricilikte, verimi yüksek ancak hastalıklara duyarlı çeşitlerin yaygın kullanımı ve sera içerisinde nemin uzun süre kalması bakteriyel hastalıkların kolaylıkla yayılmasına neden olmaktadır. Bu nedenlerle hastalık mücadelesinde çevre ve insan sağlığına zarar vermeden, tarımsal üretimin sürdürülebilir olmasına olanak veren, ekonomik ve aynı anda farklı hastalıkları baskılayan yöntemler tercih edilmelidir. Bu bağlamda hastalık yönetiminde bitki aktivatörlerinin kullanımıyla üretim boyunca bitkinin hastalıklara dayanımı sağlanabilir.

Bu araştırmada farklı bitki aktivatörlerinin ve biyolojik fungisitin domateste Bakteriyel Benek ve Kara Leke Hastalığa karşı mücadelede oldukça başarılı olduğu görülmektedir. Altı farklı ticari preparat her ne kadar farklı oranlarda başarılı olsa da yapraktaki ve gövdedeki hastalığı baskılama ve bitki büyümesine olan olumlu katkISI değerlendirildiğinde Turf-Set ve ISR-2000 uygulamaları ön plana çıkmaktadır. Ayrıca bu iki uygulama deneme sonuna kadar hastalığı baskılamada başarı göstermiştir.

$\mathrm{Bu}$ çalışmada elde edilen veriler, serada yetiştirilen domateslerde sorun olan bakteriyel hastalıkların yönetimine bitki aktivatörlerinin dahil edilebilirliğini destekler niteliktedir. Genel olarak sonuçlar değerlendirildiğinde, bitki aktivatörlerinin özellikle organik tarımda kimyasallara alternatif mücadele yöntemi olarak ümitvar olduğu düşünülmektedir. Böylece insan sağlığı ve çevreye zararlı etkisinden dolayı pestisit kullanımında da azalıs sağlanabilecektir. Özellikle bitki bakteri hastalıklarının entegre mücadele programına dahil edilerek fide dikiminden hasada kadar bitki dayanıkılığının aktif tutulmasıyla da başarı şansı artacaktır. Gelecekte yapılacak çalışmalarla bu uygulamaların bitkideki hangi dayanıklılık mekanizmasını aktive ettiğinin araştırılması faydalı olacaktır.

\section{ÖZET}

Amaç: Pseudomonas syringae pv. tomato (Okabe) Young, Dye and Wilkie, domates bitkisinde bakteriyel benek olarak bilinen hastalığa neden olur. Hastalığın mücadelesinde bakırlı preparatlar kullanılmakla birlikte, son yıllarda kullanılan bakırlı preparatlara karşı hastalık etmeninin dayanıklılık geliştirdiği bilinmektedir. Bu bağlamda sürdürülebilir tarım uygulamaları kapsamında kimyasallara alternatif çevre dostu olan mücadele yöntemlerinin kullanımı önem arz etmektedir. Bu çalışmada, domates bakteriyel benek hastalığının mücadelesinde dayanıklılığı uyaran bitki aktivatörleri ile biyolojik preparatın kullanım olanaklarının araştırılması amaçlanmıştır.

Yöntem ve Bulgular: Organik ve geleneksel üretimlerde kullanılabilen beş bitki aktivatörü (Crop-Set, ISR-2000, KingBo, Sergomil L60, Turf-Set) ve bir biyolojik preparat olan Serenade ${ }^{\circledR}$ SC (\%1.34 Bacillus subtilis QST 713)'nin bakteriyel benek hastalığına karşı etkisi plastik sera koşullarında araştırılmıştır. Elde edilen verilere göre uygulamaların yapraklardaki hastalık belirtilerini \%1650, gövdedeki belirtileri \%25-50 oranında azalttığı saptanmıştır. Yapılan değerlendirmeler sonucunda, yapraklardaki benek ve gövdedeki kara leke belirtilerini baskılamada tüm uygulamalar başarılı bulunmuş olmakla birlikte, uygulamalar arasında Turf-Set, ISR-2000 ve Sergomil en başarılı uygulamalar olarak belirlenmiştir. Söz konusu uygulamalar bitki kuru ağırlığında \%4-56 oranında artış sağlamıştır.

Genel Yorum: Yapraktaki ve gövdedeki hastalığı baskılama ile bitki büyümesine olan etki değerlendirildiğinde Turf-Set ve ISR-2000 uygulamaları en etkili uygulamalar olarak belirlenmiştir.

Çalışmanın Önemi ve Etkisi: Çalışmadan elde edilen sonuçlar, bitki aktivatörlerinin özellikle organik tarımda kimyasallara alternatif mücadele yöntemi olarak kullanılma potansiyeline sahip olduğunu göstermektedir. 
Anahtar Kelimeler: Aktivatör, biyolojik mücadele, Pseudomonas syringae pv. tomato, organik tarım, sürdürülebilir tarım.

\section{TEŞEKKÜR}

Domateste Bakteriyel Benek hastalık etmeni izolatının teminindeki desteğinden dolayı Sayın Prof. Dr. Yeşim AYSAN'a teşekkürlerimi sunarım.

\section{ÇIKAR ÇATIŞMA BEYANI}

Yazar çalışma konusunda çıkar çatışmasının olmadığını beyan eder.

\section{KAYNAKLAR}

Akbaş B (2018) Bitki hastalıklarının yönetiminde biyoteknoloji. TÜRKTOB Der. 25: 30-33.

Aktaş LY, Güven A (2005) Bitki Savunma Sistemlerinde Hormonal Sinyal Moleküller ve Çapraz-lletişimler. Çankaya Üniversitesi Fen-Edebiyat Fakültesi, J. of Arts and Sci. 3(1): 1-12.

Anonim (2021a) TUiK Bitkisel Üretim İstatistikleri. Organik Bitkisel Üretim İstatistikleri. https://data.tuik.gov.tr/Kategori/GetKategori?p=tari m-111\&dil=1 (Erişim Tarihi: 25.02.2020).

Anonim (2021b) FAO Bitkisel Üretim İstatistikleri. http://www.fao.org/faostat/en/\#data/QC/visualize (Erişim Tarihi: 16.05.2021).

Anonim (2021c) TUiK Bitkisel Üretim İstatistikleri. Bitkisel Üretim İstatistikleri. Bölgesel Domates Üretim verileri.

https://biruni.tuik.gov.tr/medas/?kn=92\&locale=tr (Erişim Tarihi: 16.05.2021).

Aysan Y, Saygılı H (2008) Domates Bakteriyel Kara Leke Hastalığı, Domates Bakteriyel Benek Hastalığı. Bitki Bakteri Hastalıkları (Editörler:Hikmet Saygılı, Fikrettin Şahin, Yeşim Aysan) sayfa:123-126. Meta Basım, İmir, 317 sayfa.

Baysal Ö, Soylu EM, Soylu S (2003) Induction of defence related enzymes and resistance by the plant activator acibenzolar-s-methyl in tomato seedlings against bacterial canker caused by Clavibacter michiganensis subsp. michiganensis. Plant Pathol. 52: 747-753.

Bozkurt IA, Soylu S, Kara M, Soylu EM (2020) Chemical Composition and Antibacterial Activity of Essential Oils Isolated from Medicinal Plants against Gall Forming Plant Pathogenic Bacterial Disease Agents. KSU Tarım ve Doğa Derg. 23: 1474-1482.

Butsenko L, Pasichnyk L, Kolomiiets Y, Kalinichenko A (2020) The effect of pesticides on the tomato bacterial speck disease pathogen Pseudomonas syringae pv. tomato. Appl. Sci. 10(9): 3263.
Çetinkaya Yıldız R, Aysan Y (2005) Bakteriyel solgunluk hastalı̆̆ etmeni (Clavibacter michiganensis subsp. michiganensis) ile bulaşık domates fidelerinde bitki aktivatörlerinin etkinliğinin belirlenmesi. Türkiye 2 . Tohumculuk Kongresi, 9-11 Kasım, 2005, Adana, 359 s.

Delisoy K, Altınok HH (2019) Kavunda fusarium solgunluk hastalı̆ına karşı bazı rizobakterilerin ve bitki aktivatörlerinin etkinliklerinin belirlenmesi. Anadolu Tar. Bil. Der. 34:135-145.

González-Hernándeza Al, Fernández-Crespoa E, Scalschia L, Reza Hajirezaeib M, von Wiren N,GarcíaAgustína P, Camañesa G (2019) Ammonium mediated changes in carbon and nitrogen metabolisms induce resistance against Pseudomonas syringae in tomato plants. J. Plant Physiol. 239: 28-37.

Herman MAB, Davidson JK, Smart CD (2008) Induction of plant defense gene expression by plant activators and Pseudomonas syringae pv. tomato in greenhousegrown tomatoes. Phytopathol. 98: 1226-1232.

Inbar J, Abramsky M, Cohen D, Chet I (1994) Plant growth enhancement and disease control by Trichoderma harzianum in vegetable seedlings grown under commercial conditions. European J. of Plant Path. 100: 337-346.

Karabay ÜN, Türküsay H, Akı C, Tosun N, Türkan I (2003) Domatesin bakteriyel hastalıklarının kontrolünde bitki aktivatörleri ve bakterisitlerin etkileri. Anadolu Ege Tarımsal Araş. Ens.Der. 13(2): 88-102.

Karaer M (2020) Farklı sulama seviyelerinin malçlı ve malçsız koşullarda yetiştirilen sofralık domatesin verim ve kalitesi üzerine etkisi. Bursa Uludağ Üniversitesi, Fen Bilimleri Enstitüsü, Biyosistem Mühendisliği Ana Bilim Dalı, Doktora Tezi, 116s.

Karman M (1971) Bitki Koruma Araştırmalarında Genel Bilgiler Denemelerin Kuruluşu ve Değerlendirme Esasları. T.C. Ministry of Agriculture Directorate of Plant Protection and Quarantine Publications, Professional Books Series, Izmir, 279 pp.

Kiracı S, Gönülal E, Padem H (2013) Mikrobiyal gübre ve bitki aktivatörü uygulamalarının organik havuç yetiştiriciliğinde kalite parametreleri üzerine etkisi, SDÜ Zir. Fak. Der. 8(2): 36-43.

Kiracı S, Karataş A (2015) Organik domates yetiştiriciliğinde bitki aktivatörü uygulamalarının verim ve kalite üzerine etkisi. Adnan Menderes Üniversitesi Zir. Fak. Der. 12(1): 17-22

Mengulluoglu M, Soylu S (2012) Antibacterial activities of essential oils from several medicinal plants against the seed-borne bacterial disease agent Acidovorax avenae subsp. citrulli. Research on Crops 13: 641-646. 
Mittler R, Blumwald E (2015) The Roles of ROS and ABA in Systemic Acquired Acclimation.The Plant Cell 27(1): 64-70.

Soykan Ö (2010) Bazı bitki aktivatörleri ile organik ve inorganik gübrelerin domateste bakteriyel solgunluk hastalığına etkisi. Çukurova Üniversitesi, Fen Bilimleri Enstitüsü, Bitki Koruma Ana Bilim Dalı, Yüksek Lisans Tezi, $58 \mathrm{~s}$

Soykan Ö, Aysan Y (2011) Bazı bitki aktivatörleri ile organik ve inorganik gübrelerin domateste bakteriyel solgunluk hastalığına etkisi. Türkiye IV. Bitki Koruma Kongresi Bildirileri, Kahramanmaraş, Sayfa 317.

Soylu S, Baysal Ö, Soylu EM (2003) Induction of disease resistance by the plant activator, acibenzolar-smethyl (ASM), against bacterial canker (Clavibacter michiganensis subsp. michiganensis) in tomato seedlings. Plant Sci. 165: 1069-1075.

Soylu EM, Soylu S, Kara M, Kurt Ş (2020) Sebzelerde sorun olan önemli bitki fungal hastalık etmenlerine karşı vermikomposttan izole edilen mikrobiyomların in vitro antagonistik etkilerinin belirlenmesi. KSU Tar. ve Doğa Der. 23: 7-18.
Sönmez K (2016) Domatesin besin içeriği ve gıda olarak değerlendirilmesi. Türkiye Tohumcular Bir. Der., Ocak-Mart 2016, 17:32-35 http://www.turktob.org.tr/dergi/makaleler/dergi17/ TTOB Dergi17 WEB-32 35.pdf

Sülü SM, Bozkurt IA, Soylu S (2016) Bitki Büyüme Düzenleyici ve Biyolojik Mücadele Etmeni Olarak Bakteriyel Endofitler. MKÜ Zir. Fak. Der. 21: 103-111.

Şahin B, Soylu S, Kara M, Türkmen M, Aydin R, Çetin H (2021) Superior antibacterial activity against seedborne plant bacterial disease agents and enhanced physical properties of novel green synthesized nanostructured ZnO using Thymbra spicata plant extract. Ceramics Intern. 47: 341-350.

Ustun N, Uluta E, Yasarakıncı N, Kılıç T (2009) Efficacy of some plant activators on bacterial canker of tomato in Aegean Region of Turkey. Act. Hort., 808: 405-408.

Ustun N, Demir G, Saygili H (2005) Possibilities for control of tomato pith necrosis by using copper compounds and plant activators. Act. Hort. 695: 321326. 